\title{
Multi-objective Model on Connection Time Optimization in Sea-rail Intermodal Transport
}

\author{
Qi Zhang, Hao Yang, Li Zhang
}

\begin{abstract}
Container sea-rail intermodal transport operation needs to consider some special demands both in volume and time connection. That means container sea-rail intermodal transport is a type of demand responsive transport between railroad trains and marine ships, vice versa. It needs to operate container trains according to the demands of ships in OD, volume, as well as the arrival and departure time. Basing on this responsive demand characteristic of sea-rail intermodal transport, the paper establishes a multi-objective optimal model for its connection time, aiming for maximizing the profits of carriers and minimizing the total transport costs of shippers, as well as minimizing the connection time between container trains and ships to optimizing the intermodal transport system. Modified genetic algorithm is adopted. The calculation results demonstrate that the model could be used to solve the connection problem of container sea-rail intermodal transport involved with volume and time connections.
\end{abstract}

Keywords-Connection time, Inland-port-transferring Railway Hub Container Transport System, multi-objective optimal model, responding transport, sea-rail intermodal transport

\section{INTRODUCTION}

CoN

ONTAINER sea-rail intermodal transport is not the same as

the regular freight transport. Its operation is beyond just one transport mode. The problems need to be settled in sea-rail intermodal transport operation include not only the original stations, terminal ports, flow volume, but also some special

demands in volume and time connections between railroad trains and marine ships. That means the container sea-rail intermodal transport is a type of demand responsive transport with train- ship connecting efficiently with each other. This connection could effectively reduce the cycle time of containers and ships, as well as the costs of them both in ports and stations. For example, something could be arranged in advance before ships berthed in harbor by the assistance of advanced information system. It could get a groundage-saving about $\$ 45000$ for a third-generation container ship. And the

larger the ship is, the more the saving is.

Manuscript submitted on June 12, 2014. This work was supported by the Fundamental Research Funds for the Central Universities (2014JBM070).

Qi Zhang. Associate professor, School of Traffic \& Transportation, Beijing Jiaotong University, Beijing, 100044, China (e-mail: qizhang@bjtu.edu.cn).

Li Zhang. Associate professor, Department of Civil and Environmental Engineering, Mississippi State University, Starkville, MS39762, USA (e-mail: lzhang@cee.msstate.edu).

Hao Yang. Professor, School of Traffic \& Transportation, Beijing Jiaotong University, Beijing, 100044, China (e-mail: hyang@bjtu.edu.cn).
Railway Hub Container Transport System (RHCTS) is defined in reference [1] as a type of transport system covering specific areas and comprising a number of container stations, which belong to different transport modes and have different capacities and functions. Every RHCTS makes one or two railway logistics center(s) as its central station. All of the containers inbound or outbound a RHCTS are gathered in the railway logistics center and transported from this central station outside the system, vice versa. This logistics center is a national or regional hub in container transport railroad network.

\section{LITERATURE REVIEWS}

There were many researchers focused their studies on containers, including freight placement in container, container transport, competitiveness of container harbors, attractive powers of regions, and so on. For example Zhang (2011), Zhu (2010)[7], Yan (2004), Worawan S (2006), Nathan N H (2005)[21], Zhou (2003), Mohammad A A (2003)[16], Hossein J (2002), Sangeeta B (2001)[25], Ebru K B (1999), Diez R (1999), Alexandra M N (1998), Elizabeth G J (1996)[15], etc. Because of the development of world trade and container ports, many researches focused on the problems of ocean shipping and container ports, including the berth availability, the equipment allocation and utilization, the matching relationship between the loading and unloading machines with transferring equipments, store yard layout and management, empty containers back-transport, and so on. Researchers studied different theories, applied different methods and developed different models to solve the above problems. The research results were abundant, both in theories and practices.

Zhang (2011)[1] studied the theories of container sea-rail intermodal transport and put forward the $5 \mathrm{R}$ rules of it. That is Right goods, Right direction, Right volume, Right time and Right port. These 5Rs stressed the responsive and cooperative relationships between two different transport modes during the whole procession. It also showed the importance of connections due to these $5 \mathrm{Rs}$ of container sea-rail intermodal transport.

Wei Yan (2005)[3], Haifeng Yan (2004)[4], Yong Zhou (2003)[6] and Guo (2008)[9] studied respectively the rank of railway container stations in Chinese rail net, the business procession of container flows within the railway container central station, as well as the types of container trains between stations. The authors established multi-objective 0-1 optimal model to optimize the operation schemes of railway container trains.

Worawan S (2006)[17] studied deeply on the vehicle 
scheduling problems under both static and dynamic conditions in large scale. The author established a nonlinear integer programming model aiming for minimizing the running time of train. The GA was applied. The model considered many inner influencing factors on train operation, such as the types and traits of trains, the speed limitation of interval and station, the related parameters of lines, and so on. The research results had some real meanings.

Hossein J, Maged D, Petros L and Anastasios C (2005)[22][23] studied deeply on the multi Travel Salesman Problem with Time Window, m-TSPTW. The authors established a two-stage optimal model based on dynamic programming to get the best route for container trailer under the conditions of city network and multi-routes. Mixed genetic algorithm was applied to solve this problem with large scale.

For the container intermodal transport, Alexandra M N (1998)[24] studied the optimal problems of operation and management in container rail-highway intermodal transport. The author studied the volume allocation both in time and transport modes in intermodal transport. The objectives of the optimal model in this research included minimizing the total operation costs and meeting the timeliness demands in container transport.

Besides, many researches focused on the operation and management problems in container ports. For example, competitiveness, efficiency, operation costs, equipment investment, storage strategy, berth availability and utilization, all of these were becoming the research themes.

Ebru K B (1999)[18] and Diez R (1999)[19] studied the operation of inner logistics system of port in site location, equipment allocation, trailer route optimization, etc, applying the queuing theory, simulating technology and optimization theory. The research covered the main problems in container harbors.

Larry H, Fredrik W and Paul D (2007)[28] studied the container port inner system by Multi-Agent System method. The authors put forward that the turnover time of ship is a crucial parameter to the efficiency and competitiveness of port. The research divided the container port inner system into four subsystems, as ship-shoreside part, transfer part, storage part, pick-up and delivery part. The authors established a systemic model with parameters drawing from the four subsystems above to allocate and coordinate the port resources by MAS method.

Maurizio B, Azedine B and Mohamed R (2006)[29] established a goal-directed simulation model for container wharf business by UML chart design method. The authors made evaluations on the procession and efficiency of business in container wharf from three aspects, evaluating the alternative schemes of loading and unloading business of ship, evaluating the storage strategy of container yard, evaluating the allocation strategy of equipments. Time and costs were the criteria of evaluations.

This paper focuses on the problem of connecting time and its optimization in sea-rail intermodal transport from inland to container port. Based on the problem description and literature review above, the main contributions of this paper are described as follows.

1) Basing on the responsive demand and $5 R$ rules of container sea-rail intermodal transport, the paper establishes a multi-objective optimal model for the connection time, aiming for maximizing the profits of carriers, minimizing the total transport costs of shippers, as well as minimizing the connection time between container railroad trains and marine ships.

2) Modified genetic algorithm is adopted. Basing on the operational facts of Zhengzhou railway container central station, the model is verified to be useful and could be used to solve the connection problem of container sea-rail intermodal transport involved with volume and time connections. And the optimal connection time is given by the results of the model.

\section{Symbol Notations of Time Connection Model}

The variables and parameters in the time connection optimal model are illustrated as follow.

$m_{s p}{ }^{k}:$ the decision variable, it means the number of railroad cars of the $k^{\text {th }}$ type of container train.

$x_{s p}{ }^{k}$ : the decision variable, it means the number of the $k^{\text {th }}$ type of container train between the railway central station $O\left(s_{i}\right)$ and container port $D\left(p_{j}\right)$.

$Q_{p}^{r e s t}$ : the rest number of containers stored in port after the ship departure, TUE.

$Q_{p}{ }^{\text {ship }}$ : the number of containers needed by the ship departing from the port in schedule, TUE/ship.

$$
n_{p}^{\text {ship }} \text { : the number of container ships having the responsive }
$$

relationships with container railroad trains and leaving from the port during the statistic time, ship.

$N_{p}$ : the total number of container ships having the responsive relationships with container railroad trains, including both in schedule and left from the port during the statistic time, ship.

$C_{p}{ }^{\text {ship }}$ : the total ocean transport costs of container ship, Yuan/TEU.

$c_{p}^{\text {truck }}{ }_{p}$ : the operation cost of trailer transferring between container yard and shore-side, Yuan/trailer.

$c_{p}{ }^{z h x}$ : the total costs of loading and unloading operations of containers in port, Yuan/TEU.

$c_{p}{ }^{z c}$ : the unit storage cost of container in port yard, Yuan/TEU.h.

It needs to note something about the $c_{p}{ }^{z c}$.

The responsive characteristic of sea-rail intermodal transport makes requirements on the operation of container railroad trains. It claims that the containers should arrive at the port in an appropriate duration. Either too early or too late arrival will 
add extra inventory costs of containers in port yard, and increase operational burden to the capability of container ports.

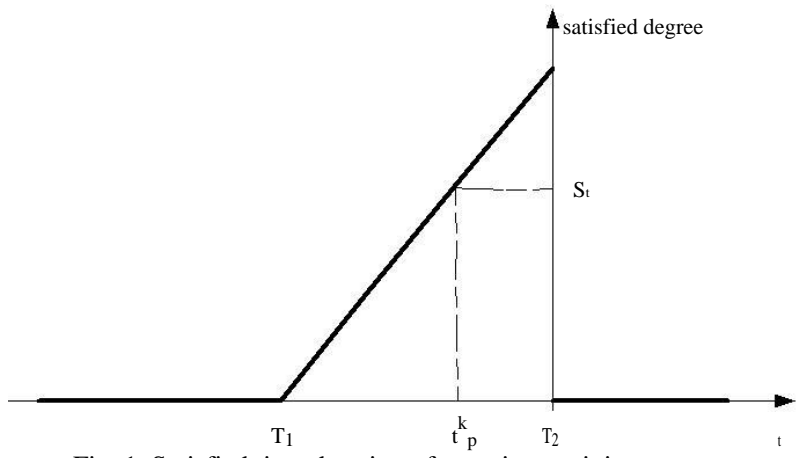

Fig. 1. Satisfied time duration of container arriving port

The appropriate arrival time in this paper is named as satisfied time duration, shown as Fig.1. The satisfied time duration $\left[T_{1}, T_{2}\right]$ is the ideal or expected interval of container arrival time. Containers arriving at port in this interval could well meet the time-connection demand of ship departure.

As Fig.1 illustrated, the earliest and latest arrival time accepted by ship are $T_{1}$ and $T_{2}$ respectively. Supposed that containers are transported by the $k^{\text {th }}$ container train to the container port named as $D(p)$. The arrival time of these containers is defined as $t_{p}{ }^{k}$. There exist three conditions as following:

--If $t_{p}{ }^{k}$ is in the ideal or expected time interval of $\left[T_{1}, T_{2}\right]$, the arrival time is satisfied.

--If $t_{p}{ }^{k}$ is in the time duration of $\left[-\infty, T_{1}\right]$, the arrival time is

too early and will arise an extra inventory costs to the container in port yard. This will not be accepted by the shippers.

--If $t_{p}{ }^{k}$ is in the time duration of $\left[\mathrm{T}_{2},+\infty\right]$, the arrival time

will be too late to catch up with the ship departure. This will cause a broken stowage and will increase the transport costs of ocean shipping, especially when the number of containers in the last arrival is big. This will not be accepted by the liners.

Notations of other variables and parameters in the optimal time connection model are as follow.

$t_{p}$ : the average inventory time of the leaving containers in port yard, h.

$T_{p}^{\text {ship }}$ : the turnover time of container ship in port, h.

$t_{p}{ }^{\text {ship }}$ : the time of loading operation of ship for unit container in wharf apron, h/TEU.

$t_{p}^{\text {truck }}$ : the turnover time of trailer for transferring the containers between the yard and the shore-side, h/trailer times. $t_{p}^{d e p}:$ the departing time of ship according to the timetable in

the port.

$T_{s p}{ }^{k-l i n e}:$ the travel time of container train from the original railway central station to container port, $h$. It is need to note that there exist a physical distance between the terminal station of railroad trains and port yard. Considering the seamless demand of sea-rail intermodal transport, we assume that the distance between the terminal station of container train and port yard could be neglected, compared with the long travel distance between OD. Those containers transported by railroad trains can be transferred to port yard directly.

$T_{s}{ }^{k}{ }_{\text {-mid }}$ : the total operational time of container train occurring in the railway central stations en route, if the train is a type of connecting train and has some operations in this station, $h$.

$T_{s}{ }^{k}$-des : the total operational time of container train occurring in the railway central station in/near the container port, including the arrival time, the unloading time and the transferring time between the terminal station and the port, $h$. According to the note above, the transferring time between the terminal station and the port could be neglected.

$\Delta t:$ the delay time of ship arising from all reasons except the loading and unloading operations and occurring during the berth time after into port and before departing port.

$\Delta T$ : the total delay time of container from leaving from the railway central station to departing from container port, $h$.

$\omega \cdot 24:$ the conversion relationship of time and date.

$\theta$ : the matching coefficient of equipment allocation in port. In loading and unloading operational system in container port, it means the ratio between the bridge cranes in wharf apron, the gantry cranes in port yard, and the trailers used for transferring between yard and wharf apron.

In general speaking, it needs 3-5 bridge cranes for the loading and unloading operations of one ship. When it allocated 3 bridge cranes, the optimal ratio between gantry crane and bridge crane is 2.286 , and 6.08 it is between trailer and bridge crane.

$\beta$ : the fluctuant coefficient of container volume, coming from the change of transport demand and supply capacity. It is an empirical value as $\beta=1.1 \sim 1.4$.

$1 / 2$ : the capacity factor of container trailer. That means the transferring capacity of one trailer is two twenty-feet container (2TEU) per time.

\section{Time Connection Optimal Model of Container SEA-RAIL TRAIN}

\section{A. Optimal Model}

According to the 5Rs rules, the responsive characteristics and the specific connection demands in both volume and time of container sea-rail intermodal transport, the paper establishes a multi-objective optimal model for inland-port-transferring RHCTS container train connection time.

The multi-objective optimal model of container sea-rail train time connection is illustrated as follows.

$$
\min Z_{1}=\beta Q_{s}^{\text {rest }}+\int_{t \text { tdao }}{ }^{t}{ }_{i j} \lambda d t-\sum_{p \in P} \sum_{P \in} 2 m_{s p}{ }_{s p}^{k} x_{s p}{ }^{k}
$$




$$
\begin{aligned}
& \min Z_{2}=Q_{p}^{r e s t}+\sum \sum_{s \in S} 2 m_{s p}{ }_{s p}^{k} x_{s p}{ }^{k}-\sum_{n \in N_{p}} n_{p}^{\text {ship }} Q_{p}^{\text {ship }} \\
& \min Z_{3}=\sum_{k \in K} 2 m_{s p}{ }^{k} x_{s p}^{k}\left(c_{p}^{z c} t_{p}+c_{p}^{z h x}\right)+
\end{aligned}
$$

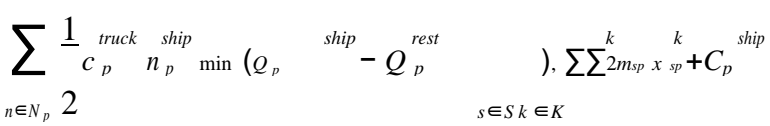

$$
\begin{aligned}
& \sum_{\in}^{s} \sum_{R_{s p}}^{s} 2 m_{s p \in P \in K}^{k} x_{s p}^{k} \leq Q_{\max }, \forall r_{s p}{ }^{k}
\end{aligned}
$$

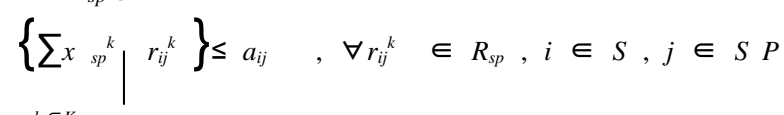

$$
\begin{aligned}
& \sum_{k \in K}^{k \in K} 2 m_{s p}^{k} x_{s p}^{k} \leq Q_{p}^{s} \quad, \forall r_{s p}{ }^{k} \in R_{s p} \\
& { }_{{ }_{p}}^{\text {ship }}=Q_{p}^{\text {ship } 1}-{ }_{p}^{t}{ }^{\text {truck }}+\frac{1}{i_{p}{ }^{\text {ship }}}+\Delta t \\
& 2 \theta \\
& \forall Q_{p}^{\text {ship }} \leq \psi_{p}{ }^{r e s t}+\sum \sum \sum_{\substack{k p s p \\
s p}}^{k} k \\
& s \in S k \in K
\end{aligned}
$$

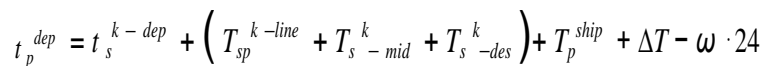

$$
\begin{aligned}
& t_{s^{k-d e p}}, t p^{d e p} \geq 0 \text {, 且 } t_{s}{ }^{k-d e p}, t_{p}^{d e p}=0 \sim 24 \\
& x_{s p}^{k}, m_{s p}^{k} \geq 0 x_{s p}^{k}, m_{s p}^{k} \in Z . \forall s \in S, p \in P, k \in K, r_{s p}^{k} \in R
\end{aligned}
$$

\section{B. Objectives and Constraints}

Objectives (1) and (2) show the goals of minimizing the rest number of containers in railway station and port yard respectively. Objective (3) expresses the goal of minimizing the total transport costs including those happened both in port and sea transport. All of these three objectives reflected the responsive characteristics and 5Rs demand of container searail intermodal transport.

Equation (4) illustrates the capacity constraint of original railway logistics central station. That means the total number of containers transported by the container trains from railway station to related container ports is no more than the maximum inventory number of containers, $Q_{\max }$, in the original railway station.

Equation (5) shows the capacity constraint of railway tracks. That means within the given period, the total number of container trains operated from the original railway logistics central station $O\left(s_{i}\right)$ to container port $D\left(p_{j}\right)$ is no more than the permitted number of trains which is restricted to the through capacity of the railroad tracks between the above OD.

Equation (6) illustrates the taking over capacity constraint of container port $D\left(p_{j}\right)$. That means within the given period, the total number of containers transported by container trains from
$O\left(s_{i}\right)$ to $D\left(p_{j}\right)$ is no more than the maximum accepting

capacity of port, $Q_{p}{ }^{s}$, which is allocated to this OD.

Equation (7) shows the turnaround time constraint of container ship in port. The prerequisite of this constraint is the volume connection constraint of responsive demand of sea-rail intermodal transport. That is to say when the given container train arrived at the yard of the port $D\left(p_{j}\right)$, all of the containers

in this train can be loaded on the ship and meet the volume connection demand of this ship. Then, the ship could depart the port on time.

Equation (8) shows the connection time constraint of the container sea-rail intermodal transport responsive demand.

That is to say the total transport time, from departing the original railway central station of inland-port-transferring

RHCTS to finishing the loading operation of container ship, including all time because of any operations and delays happed in the transportation process between the OD. This total time exhausting could meet the departure time demand of the ship according to the timetable of the container port.

Non-negative and value range constraints of decision variables are illustrated as (9) and (10). Among them, $t_{p}{ }^{d e p}$ and $t_{s}^{k-d e p}$ are both time variables. The range of values is determined according to 24-hour system. $x_{s p}{ }^{k}$ is the number of container trains operated between original railway central station $O\left(s_{i}\right)$ and container port $D\left(p_{j}\right)$. While $m_{s p}{ }^{k}$ is the number of container flatcars in one container train.

Adopting the modified Genetic Algorithm, the model could get the optimal objectives and the desired value of decision variables. And the departing time of container train from the original railway central station $t_{s}{ }^{-d e p}$ could meet the demands of departing time and volume requirement of ship from container port.

\section{Case Study of Zhengzhou I-RHCTS Sea-rail INTERMODAL TRANSPORT CONNECTION TIME}

\section{A. In One-to-one Network Conditions}

According to the time connection optimal model and applying Genetic Algorithm in a one-to-one network condition, the paper gets the optimal values of objectives as well as the connection time of Sea-Rail Intermodal Container Trains, SRICT, operated from the railway logistics central station of Zhengzhou I-RHCTS to Qingdao container port.

The results are shown in table I and table II .

TABLE I

SCHEME OF SRICT BETWEen ZHENGZHOU AND QINGDAO IN 2012

\begin{tabular}{ccccccc}
\hline $\begin{array}{c}\text { Arriving } \\
\text { port }\end{array}$ & $\begin{array}{c}\text { Departing } \\
\text { station }\end{array}$ & OD & $\begin{array}{c}\text { Running } \\
\text { cycle }\end{array}$ & $\begin{array}{c}\text { Intermedi } \\
\text { ate stop }\end{array}$ & $\begin{array}{c}\text { Train } \\
\text { style }\end{array}$ & $\begin{array}{c}\text { Train } \\
\text { length }\end{array}$ \\
\hline \multirow{2}{*}{ Qingdao } & Zhengzhou & ZZ-QD & $1 /$ per day & - & $1^{*}$ & $36 \mathrm{w}$ \\
\cline { 2 - 7 } & Xi'an & $\begin{array}{c}\text { XA)ZZ } \\
\text {-QD }\end{array}$ & 1/per day & $\begin{array}{c}\text { Zhengzh } \\
\text { ou }\end{array}$ & $2^{*}$ & $40 \mathrm{w}$ \\
\hline
\end{tabular}

Note: 
$1 *$ is a type of express and through train, one deck, with the container flow between Zhengzhou and Qingdao.

$2^{*}$ is a type of express train, one stop and one deck, with the container flows of Xi'an-Qingdao and Zhengzhou-Qingdao.

$36 \mathrm{w}$ means there're 36 container flatcars in one train.

The scheme table comes from the reference [1].

--Scheme one

The transport operation of the first type of train is illustrated as Fig.2.

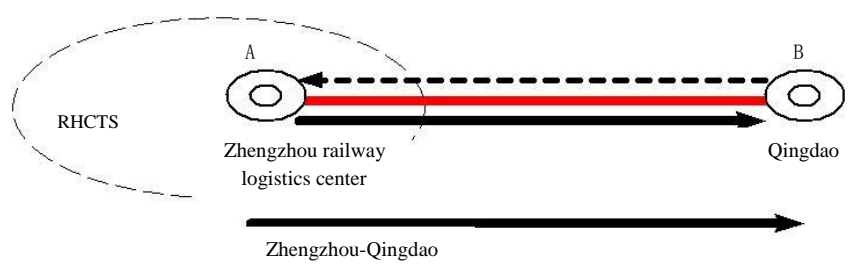

Fig. 2. Sea-rail intermodal container train between Zhengzhou-Qingdao, express, through and one deck

--Scheme two

The transport operation of the second type of train is illustrated as Fig.3.

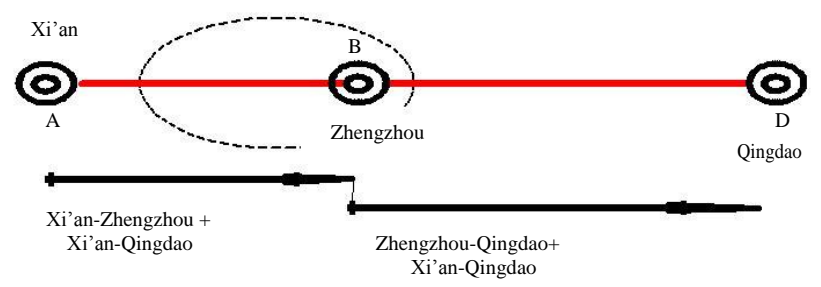

Fig. 3. Sea-rail intermodal container train between Xi'an-Qingdao, express, one-stop and one deck

--The results of optimal model for scheme one

For the through train between Zhengzhou and Qingdao, the results of optimal model are shown in table II.

TABLE II

Optimal Results of Scheme ONE BetweEn ZhengZhou ANd QINGDAO

\begin{tabular}{|c|c|c|c|c|}
\hline $\begin{array}{l}\text { Content } \\
\text { of train }\end{array}$ & Index & Unit & Values & Note \\
\hline \multirow{5}{*}{$\begin{array}{c}\text { Zhengzhou } \\
\text {-Qingdao }\end{array}$} & $Q_{s}$ & TEU & 41 & $\begin{array}{c}\text { Quantity of rest } \\
\text { containers in station }\end{array}$ \\
\hline & $Q_{p}$ & TEU & 32 & $\begin{array}{l}\text { Quantity of rest } \\
\text { containers in port yard }\end{array}$ \\
\hline & $\mathrm{C}$ & Yuan & 774592 & $\begin{array}{l}\text { Total costs including } \\
\text { port and sea shipment }\end{array}$ \\
\hline & $t_{s}{ }^{k-d e p}$ & - & $\begin{array}{l}8: 45 \mathrm{am} \text { of the } \\
\text { given day* }\end{array}$ & $\begin{array}{l}\text { Departing time of train } \\
\text { from station }\end{array}$ \\
\hline & $t_{p}^{d e p}$ & - & $\begin{array}{l}\text { 11:30am, 2days } \\
\text { later of the } \\
\text { given day }\end{array}$ & $\begin{array}{l}\text { Departing time of ship } \\
\text { from port }\end{array}$ \\
\hline
\end{tabular}

Note: supposed that the container ship will berth in the port at $6 \mathrm{pm}$ the day after the train's departure.

The calculation results of the optimal model are illustrated in table II. Actually, the container trains will run according to the timetable. The meaning of the optimal results is offering the better alternative from the timetable which is the nearest time with the optimization.

And the same method could be used to get the optimization under a one-to-many network conditions.

\section{B. In One-to-many Network Conditions}

In reality, the container transport railroad network is complex. The more conditions are one -to-many or many-to many network. It assumes that the international terminal port is given in an international multimodal transportation chain. For the one-to -many network, the original station has to determine the order of the container ports and allocate the containers to different trains in different lines to get the optimal objectives. The details could be found in reference [1].

This part applies the model and method to solve the same problem in a one-to-many network condition. It obtains the optimal values of objectives and the connection time of SRICT operated from Zhengzhou to Shanghai, Guangzhou and Lianyungang container ports respectively.

1) Zhengzhou-Shanghai Sea-rail Intermodal Container Train Scheme and Optimal Results

\section{--Scheme}

The scheme of SRICT between Zhengzhou and Shanghai is shown as table III.

TABLE III

SCHEME OF SRICT BETWEEN ZHENGZHOU AND SHANGHAI IN 2012

\begin{tabular}{ccccccc}
\hline $\begin{array}{c}\text { Arriving } \\
\text { port }\end{array}$ & $\begin{array}{c}\text { Departing } \\
\text { station }\end{array}$ & OD & $\begin{array}{c}\text { Running } \\
\text { cycle }\end{array}$ & $\begin{array}{c}\text { Intermedi } \\
\text { ate stop }\end{array}$ & $\begin{array}{c}\text { Train } \\
\text { style }\end{array}$ & $\begin{array}{c}\text { Train } \\
\text { length }\end{array}$ \\
\hline \multirow{3}{*}{$\begin{array}{c}\text { Shang } \\
\text { hai }\end{array}$} & Lanzhou & $\begin{array}{c}\text { (LZ, } \\
\text { XA)ZZ- } \\
\text { SH }\end{array}$ & $\begin{array}{c}\text { 1/every } \\
\text { 2days }\end{array}$ & $\begin{array}{c}\text { Xi'an, } \\
\text { Zhengzh } \\
\text { ou }\end{array}$ & $1^{*}$ & $38 \mathrm{w}$ \\
\cline { 2 - 7 } & Zhengzhou & $\begin{array}{c}\text { ZZ-SH } \\
\text { /LYG }\end{array}$ & 1/per day & Xuzhou & $2^{*}$ & $32 \mathrm{w}$ \\
\hline \hline
\end{tabular}

Note:

$1^{*}$ is a type of express train, one deck, two-stops with the container flows of Lanzhou-Shanghai, Xi'an-Shanghai and Zhengzhou-Shanghai.

$2^{*}$ is a type of express train, one stop and one deck, with the container flows of Zhengzhou-Shanghai, Zhengzhou-Xuzhou, Xuzhou-Shanghai and Xuzhou-Lianyungang.

The scheme table comes from the reference [1].

\section{--Optimal results}

For the first type of container train, the calculation results are shown as table IV.

TABLE IV

Optimal Results of First Type of Train of Zhengzhou-ShanghaI

\begin{tabular}{|c|c|c|c|c|}
\hline $\begin{array}{l}\text { Content } \\
\text { of train }\end{array}$ & Index & Unit & Values & Note \\
\hline \multirow{6}{*}{$\begin{array}{l}\text { (Lanzhou, } \\
\text { Xi'an) } \\
\text { Zhengzhou } \\
\text {-Shanghai }\end{array}$} & \multirow{2}{*}{$Q_{s}$} & TEU & 13 & $\begin{array}{l}\text { Quantity of rest } \\
\text { containers in station }\end{array}$ \\
\hline & & TEU & 44 & Quantity of rest \\
\hline & $\begin{array}{l}Q_{p} \\
\mathrm{C}\end{array}$ & Yuan & 550368 & $\begin{array}{l}\text { containers in port yard } \\
\text { Total costs including } \\
\text { port and sea shipment }\end{array}$ \\
\hline & $k$-dep & - & $22: 17$ of the & Departing time of train \\
\hline & $t_{s}$ & & given day* & from station \\
\hline & $t_{p}^{d e p}$ & - & $\begin{array}{c}\text { 13:30, the third } \\
\text { day after the } \\
\text { given day }\end{array}$ & $\begin{array}{l}\text { Departing time of ship } \\
\text { from port }\end{array}$ \\
\hline
\end{tabular}

2) Zhengzhou-Guangzhou Sea-rail Intermodal Container Train Scheme and Optimal Results 
--Scheme

The scheme of SRICT between Zhengzhou and Guangzhou is shown as table $\mathrm{V}$.

TABLE V

SCHEME OF SRICT BETWEEN ZHENGZHOU AND GUANGZHOU IN 2012

\begin{tabular}{ccccccc}
\hline $\begin{array}{c}\text { Arriving } \\
\text { port }\end{array}$ & $\begin{array}{c}\text { Departing } \\
\text { station }\end{array}$ & OD & $\begin{array}{c}\text { Running } \\
\text { cycle }\end{array}$ & $\begin{array}{c}\text { Intermedi } \\
\text { ate stop }\end{array}$ & $\begin{array}{c}\text { Train } \\
\text { style }\end{array}$ & $\begin{array}{c}\text { Train } \\
\text { length }\end{array}$ \\
\hline \multirow{2}{*}{$\begin{array}{c}\text { Guang } \\
\text { zhou }\end{array}$} & Zhengzhou & ZZ-GZ & $1 /$ per day & - & $1^{*}$ & $42 \mathrm{w}$ \\
\cline { 2 - 7 } & Urumqi & $\begin{array}{c}(\mathrm{U}, \text { LZ) } \\
\text { zZ-GZ }\end{array}$ & $1 /$ per day & LZ,ZZ & $2^{*}$ & $38 \mathrm{w}$ \\
\hline Note: & & & & &
\end{tabular}

$1 *$ is a type of express through train, one deck, with the container flow between Zhengzhou and Guangzhou.

$2 *$ is a type of express train, one deck, two-stops with the container flows of Urumqi-Zhengzhou, Urumqi-Guangzhou, Lanzhou-Guangzhou and some Zhengzhou-Guangzhou.

The scheme table comes from the reference [1].

--Optimal results

For the first type of container train, the calculation results are shown as table VI.

TABLE VI

Optimal Results of First Type of Train of Zhengzhou-GuangZhou

\begin{tabular}{|c|c|c|c|c|}
\hline $\begin{array}{l}\text { Content } \\
\text { of train }\end{array}$ & Index & Unit & Values & Note \\
\hline \multirow{7}{*}{$\begin{array}{l}\text { Zhengzhou- } \\
\text { Guangzhou }\end{array}$} & $O$ & TEU & 31 & $\begin{array}{c}\text { Quantity of rest } \\
\text { Q }\end{array}$ \\
\hline & $\mathcal{Q}_{p}$ & TEU & 34 & $\begin{array}{l}\text { Quantity of rest } \\
\text { containers in port yard }\end{array}$ \\
\hline & $\mathrm{C}$ & Yuan & 428064 & $\begin{array}{l}\text { Total costs including } \\
\text { port and sea shipment }\end{array}$ \\
\hline & $k-d e p$ & - & $14: 33$ of the & Departing time of train \\
\hline & $t_{s}$ & & given day* & from station \\
\hline & $d e p$ & - & $18: 30$, the fifth & Departing time of ship \\
\hline & $t_{p}$ & & $\begin{array}{l}\text { day after the } \\
\text { given day }\end{array}$ & from port \\
\hline
\end{tabular}

3) Zhengzhou-Lianyungang Sea-rail Intermodal Container Train Scheme and Optimal Results

--Scheme

The scheme of SRICT between Zhengzhou and Lianyungang is shown as table VII.

TABLE VII

SCHEME OF SRICT BETWEEN ZHENGZHOU AND LIANYUNGANG IN 2012

\begin{tabular}{ccccccc}
\hline $\begin{array}{c}\text { Arriving } \\
\text { port }\end{array}$ & $\begin{array}{c}\text { Departing } \\
\text { station }\end{array}$ & OD & $\begin{array}{c}\text { Running } \\
\text { cycle }\end{array}$ & $\begin{array}{c}\text { Intermedi } \\
\text { ate stop }\end{array}$ & $\begin{array}{c}\text { Train } \\
\text { style }\end{array}$ & $\begin{array}{c}\text { Train } \\
\text { length }\end{array}$ \\
\hline \multirow{2}{*}{$\begin{array}{c}\text { Lianyun } \\
\text { gang }\end{array}$} & Zhengzhou & $\begin{array}{c}\text { ZZ- } \\
\text { LYG }\end{array}$ & $1 /$ per day & - & $1^{*}$ & $25 \mathrm{w}$ \\
\cline { 2 - 7 } & Urumqi & $\begin{array}{c}\text { (U,XA) } \\
\text { ZZ- } \\
\text { LYG }\end{array}$ & $1 /$ per day & XA,ZZ & $2^{*}$ & $43 \mathrm{w}$ \\
\hline \hline
\end{tabular}

$1^{*}$ is a type of express through train, one deck, with the container flow between Zhengzhou and Lianyungang.

$2 *$ is a type of express train, one deck, two-stops with the container flows of Urumqi-Lianyungang, Xi'an-Lianyungang and Zhengzhou-Lianyungang.

The scheme table comes from the reference [1].

--Optimal results

For the first type of container train, the calculation results are shown as table IV.

TABLE IV
Optimal Results of FiRst Type of Train of ZhengZhou-Lianyungang

\begin{tabular}{|c|c|c|c|c|}
\hline $\begin{array}{l}\text { Content } \\
\text { of train }\end{array}$ & Index & Unit & Values & Note \\
\hline & $Q_{s}$ & TEU & 10 & $\begin{array}{c}\text { Quantity of rest } \\
\text { containers in station }\end{array}$ \\
\hline & $Q_{n}$ & TEU & 26 & $\begin{array}{l}\text { Quantity of rest } \\
\text { containers in port yard }\end{array}$ \\
\hline $\begin{array}{c}\text { (Lanzhou, } \\
\text { Xi'an) } \\
\text { Zhengzhou }\end{array}$ & $\mathrm{C}$ & Yuan & 764400 & $\begin{array}{l}\text { Total costs including } \\
\text { port and sea shipment }\end{array}$ \\
\hline & $t_{s}{ }^{k-d e p}$ & - & $\begin{array}{l}19: 25 \text { of the } \\
\text { given day* }\end{array}$ & $\begin{array}{l}\text { Departing time of train } \\
\text { from station }\end{array}$ \\
\hline & $t_{p}^{d e p}$ & - & $\begin{array}{l}5: 30 \mathrm{am} \text {, the } \\
\text { third day after } \\
\text { the given day }\end{array}$ & $\begin{array}{l}\text { Departing time of ship } \\
\text { from port }\end{array}$ \\
\hline
\end{tabular}

\section{CONCLUSIONS}

The calculation results of optimal model are in accordance with the operation facts of Zhengzhou railway container central station. The multi-objective optimal model is valid and can be used in a complex rail-network in container sea-rail intermodal transport.

\section{ACKNOWLEDGMENT}

Besides the sponsor and financial support acknowledgments above, the authors gratefully acknowledge Chinese Railway Container Transportation Co. Ltd for providing the data that form the basis for this paper.

\section{REFERENCES}

[1] Qi Zhang, Theory Research on the Sea-rail Combined Container Transport Organization of the Inland-port-transferring Railway Hub Container Transport System, Beijing: Beijing Jiaotong University, 2011.

[2] Beijing Jiaotong University, Research on the Operation Scheme and Transport Organization of Container Train between Railway Logistics Central Stations and Special Handling Stations, Beijing: Beijing Jiaotong University, 2008.

[3] Wei Yan, Research on the Container Transport Organization between Railway Special Stations, Chengdu: Southwest Jiaotong University, 2005.

[4] Haifeng Yan, Theory and Method Research on the Container Transport Organization between Railway Center Stations, Chengdu: Southwest Jiaotong University, 2004.

[5] Haifeng Yan, Qiyuan Peng, Yong Yin, "Research on optimal model of container train scheme plan", Chinese Railway Journal, vol.25, Oct. 2003, pp. 14-18.

[6] Yong Zhou, Qiyuan Peng, Haifeng Yan, "Research on container transport organization ways within the attractive areas of railway center station", Chinese Railway Science, Jun. 2003, pp. 124-128.

[7] Xiaoning Zhu, Container Transport and Multi-modal Transportation, Beijing: Chinese Railway Publishing House, 2010.

[8] Jianjun Liu, Coordination Theory and Method on Container Transport in Port Hub, Beijing: Beijing Jiaotong University, 2004.

[9] Guofei, Research on the Transport Organization of Container Trains between Railway Container Logistics Centers, Beijing: Bejing Jiaotong University, 2008.

[10] Luo Meifeng, Container transportation service demand simulation model for United States coastal container ports, Kingston: University of Rhode Island, 2002.

[11] Kuifang Fu, "Passageway planning for container sea-rail intermodal transport in Tianjin port", Comprehensive transport, Oct. 2003, pp. 34-35.

[12] Zhong Wei, Jinsheng Shen, "Research on shortest time path and transport cost model for multi-modal transport", Chinese Engineering Science, Aug. 2006, pp. 61-64.

[13] Qiuqiu Yang, Hui Wang, "Multi-objectives optimal model for container multi-modal transportation based on genetic algorithm", Logistics Technology, vol. 29, 2006, pp. 29-31. 
[14] Rong Zhang, Panyu Yan, "Analyses and suggestion for container searail intermodal transport reality of Yangshan port", Chinese ports, Aug. 2006, pp. 25-27.

[15] Elizabeth Gwynn Jones, Managing Containers in Marine Terminals: An Application of Intelligent Transportation Systems Technology to Intermodal Freight Transportation, Austin: University of Texas at Austin, 1996.

[16] Mohammad Ali Alattar, Multi-objective optimization for inter-modal container freight terminals: Mathematical modeling of transport and operations, Los Angeles: University of Southern California, 2003.

[17] Worawan Suteewong, Algorithms for solving the train dispatching problem for general networks, Los Angeles: University of Southern California, 2006.

[18] Ebru Korular Bish, Theoretical analysis and practical algorithms for operational problems in container terminals, Illinois: Northwestern University, 1999.

[19] Diez Roux, Esteban, Storage capacity for import containers at seaports, Berkeley: University of California, Berkeley, 1999.

[20] Yann Alix, Issues in the geographical pattern of Canadian container flows across the North American continent, Montreal: Concordia University of Montreal, 1999.

[21] Nathan Nhan Huynh, Methodologies for reducing truck turn time at marine container terminals, Austin: The University of Texas at Austin, 2005

[22] Hossein Jula, Modeling and dynamic optimization of container movement in metropolitan networks, Los Angeles: University of Southern California, 2002.

[23] Hossein Jula, Maged Dessouky, Petros Ioannou, Anastasios Chassiakos, "Container movement by trucks in metropolitan networks: modeling and optimization", Transportation Research, Part E, vol. 41, 2005, pp. 235-259.

[24] Alexandra Mary Newman, Optimizing intermodal rail operations, Berkeley: University of California, Berkeley, 1998.

[25] Sangeeta Bansal, Organizational Mode Choice in International Container Shipping, New Brunswick: The State University of New Jersey, 2001.

[26] Jose Tongzon, "Efficiency measurement of selected Australian and other international ports using data envelopment analysis", Transportation Research, Part A, vol. 35, 2001, pp. 107-122.

[27] Marcel G., Dagenais, Fernand Martin, "Forecasting containerized traffic for the port of MONTREAL (1981-1995)", Transportation Research, Part A, vol. 21, 1987, pp. 1-16.

[28] Larry Henesey, Fredrik Wernstedt, Paul Davidsson, "A market-based approach to container port terminal management", European Journal of Operational Research, vol. 182, 2007, pp. 35-40.

[29] Maurizio Bielli, Azedine Boulmakoul, Mohamed Rida, "Object oriented model for container terminal distributed simulation", European Journal of Operational Research, vol. 175, 2006, pp. 1731-1751.

[30] Qi Zhang, Hao Yang, "Research on Problems of Transformation from Container Joint Port to Modern Logistics Center", Conf. System Dynamics and Management Science China, 2005, p. 730-735.

[31] Qi Zhang, Hao Yang, "Research on the Evaluation to the Level of Container Development of the Railway Logistics Center Attractive Area Based on the DEA Method", Conf. Production and Operation Management China, 2008, p. 56-59.

[32] Qi Zhang, Hao Yang, "Research on Types of Railway Hub Container Transport System Based on the Clustering Analysis Method", $9^{\text {th }}$ Wuhan International Conference on E-Business China, 2010, p. 2857-2863.

Qi Zhang (Female), Associate professor of School of Traffic \& Transportation, Beijing Jiaotong University. Dr. Zhang got her Master and Ph.D. in Beijing Jiaotong University, majoring in traffic and transportation planning and management. The main research directions of Dr. Zhang are traffic and transportation planning and management, freight transportation, intermodal transportation, and logistics.

Hao Yang (Male), Professor of School of Traffic \& Transportation, Beijing Jiaotong University. Professor Yang majors in traffic and transportation planning and management. The main research directions of Professor Yang are traffic and transportation planning and management, transportation theory of railroad, model and algorithm in transportation.

Li Zhang (Male), Associate professor of Department of Civil and Environmental Engineering, Mississippi State University. The main research directions of Dr. Zhang include the transportation system analysis, traffic modeling, traffic operations, distributed traffic simulation, traffic control algorithms, operations research and dynamic traffic assignment. Those areas of research have been successfully applied to solve the problems in intelligent transportation systems, traffic engineering, intermodal transportation, optimizing road geometric design, highway rail grade crossing, evacuation studies, traffic control and signal systems (include preemption and priority), work zone traffic studies, transportation safety, and GIS/GPS application in transportation. 